\title{
Quest For The Harmony: On the Vienna Reservations Regime and International Human Rights Treaties
}

\author{
Uyum Arayışı: Viyana Çekinceler Rejimi ve Uluslararası İnsan Hakları Andlaşmaları \\ Üzerine
}

\section{Gulsum Kaya' ${ }^{1}$}

\begin{abstract}
The reservation is one of the most important and controversial topics in international treaty law. The validity of reservations and their application came to the fore and customary reservation rules were reviewed with the Convention on the Prevention and Punishment of the Crime of Genocide in international law. Also, in the Vienna Convention on the Law of Treaties, rules on reservations were codified, which were asserted as the rules of customary international law. However, in human rights treaties, because of their distinctive characteristics, the rules of reservations needed to be applied and interpreted compatible to these particularities.

First of all, human rights treaties are different from standard contractual treaties and they do not create a balanced system between the state parties' rights and obligations. Therefore, the reciprocal effect of the reservation which gives equivalency to the parties' rights and obligations cannot function properly in human rights treaties. The second aspect is the main ideal of ensuring the universality of human rights which challenges the integrity of these treaties. The choice between integrity and universality gives us a hint about the status of the treaties regarding reservations. Another issue is the compliance of a reservation with the object and purpose of the treaty which is rated among the main rules about validity of a reservation in the Vienna Convention on the Law of Treaties. In human rights treaties, a reservation's compatibility with the object and purpose and even determining the object and purpose of the treaty is controversial. In this context two different mechanisms issuing from the Vienna Convention - opposability and permissibility- will be handled to determine the validity of the reservations in international human rights treaties.
\end{abstract}

In this paper, within the scope of the human rights treaties' aspects stated above, the application and the validity of the reservations to international human rights treaties will be discussed by assessing the solutions in the ILC's Guide to Practice on Reservations.

\section{Keywords}

Reciprocity, Permissibility of reservations, Monitoring body, Opposability doctrine, Compatibility with the object and purpose

\section{Öz}

Çekinceler andlaşmalar hukukunun önemli ve tartışmalı konularındandır. Bunların geçerliliği ve uygulanması Soykırım Suçunun Önlenmesi ve Cezalandırılması Sözleşmesi ile gündeme gelmiş ve çekincelere ilişkin teamül kuralları bu danışma görüşünde gözden geçirilmiştir. Viyana Andlaşmalar Hukuku Sözleşmesi ile ise çekincelere ilişkin teamül kurallarının kodifiye edildiği kabul edilmektedir. Ancak bu kurallar insan hakları andlaşmalarına uygulanırken bu andlaşmaların farklı nitelikleri gereğince yorumlanmaları ihtiyacı ortaya çıkmıştır.

Öncelikle sözleşmesel uluslararası andlaşmalardan farklı olarak insan hakları andlaşmalarında tarafların hakları ve yükümlülükleri bakımından bir denge gözetilmemektedir. Bu nedenle de taraflara haklar ve yükümlülükler bakımından denklik sağlayan karşılıklııı ilkesi insan hakları andlaşmalarına ileri sürülen çekincelerde tam olarak işlememektedir. 
İkinci olarak insan hakları andlaşmaları evrensellik ve bütünlük geriliminin yaşandığı türden andlaşmalardır, zira daha fazla insanın haklarının düzenlenmesi ideali kimi hallerde andlaşmanın bütünlüğünü tehdit eden bir hal alabilecektir. Ayrıca andlaşmanın konu ve amacı ile bağdaşırlık bir çekincenin geçerliliği bakımından Viyana Andlaşmalar Hukuku Sözleşmesinde getirilmiş esas niteliğinde bir kuraldır, ancak bir çekincenin konu ve amaç ile bağdaşırlığına karar vermek hatta konu ve amacı tespit etmek oldukça tartışmalı hususlar olagelmiştir. Bu bağlamda kabul edilebilirlik ve itiraz edilebilirlik çekincelerin geçerli olup olmadığının değerlendirilmesinde iki farklı yöntem olarak VAHS'nde yer almaktadır.

Bu çalışmada çekinceler rejiminin hukuk yaratıcı niteliğe sahip insan hakları andlaşmalarında uygulanması ve çekincelerin geçerliliği Uluslararası Hukuk Komisyonu'nun Uygulama Rehberi'nde getirdiği çözüm önerilerine değinilerek tartışılacaktır.

Anahtar Kelimeler

Karşılıklılık, İzin verilebilirlik, Denetim mekanizması, İtiraz edilebilirlik doktrini, Konu ve amaca uygunluk

\section{Quest for the Harmony: On the Vienna Reservations Regime and International Human Rights Treaties}

International human rights treaties can be described as treaties which are based upon norms related to human rights and aiming to create a normative system for the protection of human rights in the international area. The statement under article 1/3 of the United Nations (UN) Charter "To achieve international co-operation in promoting and encouraging respect for human rights and fundamental freedoms for all without distinction as to race, sex, language, or religion" shows the objectives and principles of the UN in international human rights law. In addition to that, other articles in the UN Charter show the importance attributed to human rights. For instance, in the preamble of the Charter it is stated that during the foundation of the UN "to reaffirm faith in fundamental human rights, in the dignity and worth of the human person, in the equal rights of men and women and of nations large and small" is regarded amongst the high goals of the state parties. Another sign for the attributed importance to human rights is the adoption of the Universal Declaration of Human Rights within three years as of the establishment of the UN and afterward the momentous number of human rights treaties adopted under the shelter of the $\mathrm{UN}^{1}$.

In the Universal Declaration of Human Rights (UDHR), having the international order which allows people to enjoy rights and freedoms, is counted also as a right in article $28^{2}$ as well. This provision and the general tendency confirms that for an international community to enjoy rights and freedoms is one of the fundamental aims of the UN. These aspects of the international system which are crystallized around the UN, show the guiding spirit of international human rights treaties.

1 UN treaties under the domain of human rights e. g.: Convention on the Prevention and Punishment of the Crime of Genocide (approved and proposed for signature 9 December 1948, entry into force 12 January 1951), Convention related to the Status of Refugees (adopted 28 July 1951, entry into force 22 April 1954), International Convention on the Elimination of All Forms of Racial Discrimination (adopted 21 December 1965, entry into force 4 January 1969), International Covenant on Civil and Political Rights (adopted 16 December 1966, entry into force 23 March 1976)

2 Everyone is entitled to a social and international order in which the rights and freedoms outlined in this Declaration can be fully realized. 
The purpose of international human rights treaties is, as stated by the Special Rapporteur of the International Law Committee; not to set forth the rights and freedoms which states accepted reciprocally, but to constitute general international norms which parties can observe in their territories and reflect the shared values ${ }^{3}$. In this way, international human rights treaties can strive to create a normative order, they are accepted as law-making treaties and so they can be distinguished from contractual treaties categorically.

International Human Rights Law, in the new world order established with the UN, becomes an international law system emanating from the treaties, customary law, international practices and the case-law of the international judicial bodies or the independent committees and whose real respondent is the individual ${ }^{4}$. Major functional tools for the protection of human rights are the treaties and in this sense, the consent of states has a distinct importance 5 . While taking individual as the beneficiary, human rights treaties create obligations to state parties with the consent of states. Also, the number and trend of human rights treaties show the collective will of international society on the topic and make it essential to argue the international treaty system to reveal its suitability with international human rights treaties especially the reservations regime of the international treaty system.

The Vienna Convention on the Law of Treaties (VCLT) regulates applicable rules in international treaties including the ones in international human rights law. However, in some aspects, the VCLT may not be suitable especially with law-making treaties and human rights treaties as normative, law-making treaties may need special treatment. The VCLT reflects and suits the classic treaty system, regardless of the type of treaty, VCLT is the lex generalis in treaty law. If a specific treaty does not regulate a special reservations system, the VCLT is going to be applied to it. But in some cases a human rights treaty can establish its own reservations system. In the European Convention on Human Rights (ECHR), article 57 regulates the reservation rules for this treaty and permits states formulating reservations for any particular provision to the extent of the inconformity of the provision in the treaty and the domestic law in force. Article 57 also has two restrictions; one, a reservation should not have a general character, and two, the brief statement about the domestic law rule concerned. Even though a treaty may include a special reservations system, it must be mentioned that the ECHR regulation is exceptional and generally human rights treaties do not include lex specialis on the issue. According to the VCLT rules, a treaty's silence on reservations has two main consequences: States can formulate reservations to the treaty and the VCLT rules are going to be applied.

3 ILC, 'Second Report on Reservations to Treaties by Mr. Alain Pellet, Special Rapporteur' (10 May-13 June 1996) UN Doc A/CN.4/477\&Corr.1\&2 and Add.1\&Corr.1-4, para 84.

4 Mahmut Göçer, Uluslararası Hukuk ve İnsan Haklarının Uluslararası Korunması (Seçkin 2002) 21.

5 ibid 26. 
This study displays the Vienna reservations system within the scope of human rights treaties and the International Law Commission's (ILC) Guide to Practice on Reservations. At first, the need for a reservations system will be handled, on behalf of the protection of human rights unconditionally, human rights treaties should choose the integrity or, as a challenging idea, the universality of human rights treaties. The second topic will be the insistence on the permissibility doctrine and why reciprocity does not function in human rights treaties. And lastly we will move on to the institutionalization demands for the application of general rules on reservations.

\section{Essentiality of a Reservations Regime: Universality and Integrity}

A treaty conveys a selection between two choices which contains a contrast within integrity and maximum participation, through the applicable reservations regime ${ }^{6}$. The first option gives priority to the integrity of the treaty and also a common practice between whole parties, therefore reservations were delimited. The second option gives priority to the universality of the treaty and reservations would be unrestrained, also more states become parties to this sort of treaty. In the first option, the state parties would be limited in number. In the second option, more states will be part. However with the reservations, not all rights and obligations in the treaty bind every state party in practice. Between these two options the question would be the preference of the international community.

Concerning the existence of the reservation rules in VCLT article 19, it can be said that the international system supports the flexibility of treaties. However, to create a balance with integrity, in the same article the compatibility test is suggested. This test is used for reviewing the reservation if it is compatible with the object and purpose of the treaty, but if the specific treaty does not entrust an authority to evaluate the compatibility of reservations, consequences arise subjectively because every state party can evaluate the reservation individually.

Minimizing the dissimilarities between the anticipations of states and associating them in the same treaty system could be possible by enabling reservations, even if the integrity of the treaty is ignored, the consensual power of the treaties advances the international law ${ }^{7}$. Harboring the tension between universality and integrity is also asserted by the UN as the fundamental feature of the human rights treaties ${ }^{8}$. In the Genocide Case, the difference between the majority opinion and the dissenting opinion is generally based on this tension. Judges representing the majority opinion supports

6 Erkan Akdoğan, Belirsizlik Kuramı Yönünden Uluslararası Andlaşmalarda Çekinceler (Yetkin 2018) 184.

7 Catherine Logan Piper, 'Reservations to Multilateral Treaties, The Goal of Universality' (1985) 71 Iowa Law Review 295 , 322.

8 ILC, Fourteenth Report on Reservations to Treaties, by Mr. Alain Pellet, Special Rapporteur (2 April, 22 May and 7 August 2009) UN Doc A/CN.4/614, 32. 
the idea that as much state as possible must become party to a treaty which stands for universality ${ }^{9}$, on the other hand judges representing the dissenting opinion support that the main aim is to fulfill the general obligations, and conclude "it would be better to lose a state as a party to the convention which insists in face of objections on a modification of the terms of the convention than to permit it to become a party against the wish of a state or states which have irrevocably and unconditionally accepted all the obligations of the convention" ". The discrepancy between these two ideals is the core of the debate. If we need to choose one of them for a solution, then we have two possibilities. In the first option, to achieve universality, rules about reservations must be flexible and broad, however in the second option for integrity, the uniformity of consent needs to be protected ${ }^{11}$ through designing strict reservation rules.

The single and exact way to assure the absolute integrity of the treaty is to prohibit reservations ${ }^{12}$, with respect to this, it can be said by relying on the existence of article 19, the VCLT system does not protect absolute integrity in principle. In the case of human rights treaties, they are not for a limited group of states aiming for limited goals, they are based on the aim of creating global norms adopted by most states ${ }^{13}$. Seeking absolute integrity inevitably decreases the number of state parties. The proportion of the beneficiaries also decreases relatively to the decline in the number of state parties, so the normative system which will be created by the human rights norms, loses its comprehensiveness. That the Vienna system permits reservations is appropriate for the human rights treaties in this context, but the alleged problems come up with practice.

The national or international inconsistencies form a state party's conduct in human rights treaties and the alternative of a state participation in a treaty by declaring a reservation may not be ratifying it without the reservation but opting out of $\mathrm{it}^{14}$. Because of this conduct, reservations must be approached as a strengthening component which assists universality instead of a weakness abolishing the integrity ${ }^{15}$.

In conclusion, a normative treaty creates an order which is intended to have broader participation but also has to constitute a perfect body of rules to function well. This is the background of the reservation's compatibility with the object and purpose test. Apart from the situation in which a treaty prohibits reservations in itself, the important

9 Reservations to the Convention of Genocide (Advisory Opinion) $1951<\mathrm{https} / /$ www.icj-cij.org/files/case-related/12/01219510528-ADV-01-00-EN.pdf > accessed 25 September 2019 [30 ff].

10 ibid 34.

11 Alain Pellet, Daniel Müller, 'Reservations to Human Rights Treaties: Not An Absolute Evil...' in Ulrich Fastenrath and others (eds), From Bilateralism to Community Interest (OUP 2011) 523.

12 ibid 524; UNGA 'Report of the International Law Commission' UN GAOR 61th Session Supp No 10 UN Doc A/61/10 (2006) 318.

13 Elena A. Baylis, 'General Comment 24: Confronting the Problem of Reservations to Human Rights Treaties' (1999) 17 Berkeley Journal of International Law 277, 288.

14 Massimo Coccia, 'Reservations to Multilateral Treaties on Human Rights'(1985) 15 California Western International Law Journal 1, 22.

15 ibid 15. 
thing is to protect the efficiency and essence of the treaty ${ }^{16}$. For this test, a reservation would be valid if it is compatible with the object and purpose of the treaty, which stops reservations from posing a threat to the integrity of the treaty. As stated, universality and integrity do not necessarily exclude each other. Following the referred doctrinal views, these two aspects are not in contradiction in human rights treaties, they are twin ideals ${ }^{17}$. The aim must be to harmonize and choose a midway between them. As for us, there is no need for a selection among these two, but in treaties including human rights as a catalog-list, universality becomes more preferable by providing international protection to more rights of more people at least. Especially universal human rights treaties bind states from different cultural, religious backgrounds and such a treaty system could be achieved by permitting reservations. For Klabbers, there is no dilemma between choosing universality or integrity, the choice is accepting the values of the other parties ${ }^{18}$. In this manner, the international system must allow reservations and have a system which is applicable also in human rights treaties.

\section{Reservations to International Human Rights Treaties and the Principle of Reciprocity}

The principle of reciprocity - which is fundamental for the contractual basis of international treaty law - refers to a balance between the parties of a treaty while undertaking the liabilities and enjoying the rights. Thus the traditional system of multilateral treaties is based upon contractual considerations and absolute congruence of each state party ${ }^{19}$. However, in human rights treaties, the rights do not belong to the state parties, rather they regulate the obligations of states that they owe to their nationals, residents or those in their territorial jurisdiction. So the contractual balance between the rights and obligations has no place in human rights treaties and the obligations not owed to the other state parties. Also, the reciprocity notion as a tool to maintain the balance between states has a contractual characteristic ${ }^{20}$. International treaties which do not have a contractual nature also do not pursue the balance of one state party's rights and obligations from that treaty with reciprocity.

The effect of the reciprocity in the reservation rules can be seen in the VCLT. A reservation has the same effect on the reserving state and the accepting state in their bilateral relation, the aim is to balance the advantages of the states originating

\footnotetext{
16 Göçer (n 4) 61.

17 Pierrick Devidal, 'Reservations, Human Rights Treaties in the 21st Century: from Universality to Integrity' (LLM thesis, Georgia Law, 2003) 48.

18 Jan Klabbers, 'On Human Rights Treaties, Contractual Conceptions and Reservations' in Ineta Ziemele (ed), Reservations to Human Rights Treaties and the Vienna Convention Regime: Conflict, Harmony or Reconciliation (Martinus Nijhoff Publishers 2004) 181.

19 Akdoğan (n 6) 201.

20 Klabbers (18) 158.
} 
from the reservation ${ }^{21}$. The articles in the VCLT including the reciprocal effect about reservations are especially these:

-21/1-b: "modifies those provisions to the same extent for that other party in its relations with the reserving State."

-21/3: "When a State objecting to a reservation has not opposed the entry into force of the treaty between itself and the reserving State, the provisions to which the reservation relates do not apply as between the two States to the extent of the reservation."

A reservation shows the reserving party's tendency to incline the terms in the relevant provision according to its particular destination. An automatic mechanism of reciprocity restrains the violation of the treaty balance and constitutes an optimized cooperation between the state parties ${ }^{22}$, because it affects both sides' rights and obligations. Instead of formulating reservations to achieve cooperation, states could have voiced their intent during the negotiation process, and would not pursue the solution by declaring a reservation. In the end, this will bring a more consensual text in its real meaning, and also bears as a more robust system especially in the international human rights treaties.

The organization of a treaty, whether it is multilateral or bilateral, is the exchange of rights and obligations. In a multilateral treaty, dual relations within two state parties are formed by reciprocity. Even multilateral human rights treaties build bilateral and separate relations between states, but the ground of difference about reciprocal application from contractual treaties is not their multilateral character but their law-making character ${ }^{23}$. Existence of a reservation aims for the elimination of the legal effect of a provision; also the reciprocal impact of an accepted reservation results with the elimination of the legal effect of that provision mutually. Since human rights treaties aim to constitute a common order rather than the exchange of rights and obligations, accepting a reservation related to elimination of an obligation would not mean elimination of the obligation for the accepting state to ${ }^{24}$. Because even if a state is party of a human rights treaty, the beneficiaries of it are the citizens of state parties or the residents in its territory, in general. States become party to a transaction that takes part in the international area, but have impacts in their domestic politics ${ }^{25}$. Human rights treaties have a hybrid structure, they are both law and contract, because of their constitutional aspect ${ }^{26}$. In this case, human rights

21 Aydoğan Özman, Milletlerarası Andlaşmalarda Çekinceler (İhtirazi Kayıtlar) (Sevinç 1970) 96.

22 Francesco Parisi, Catherine Ševčenko, 'Treaty Reservations and The Economics of Article 21(1) of the Vienna Convention' (2003) 21 Berkeley Journal of International Law 1, 20.

23 Catherine Brölmann, 'Law-Making Treaties: Form and Function in International Law' (2005) 74 Nordic Journal of International Law 383, 390.; Cooperation basis-the law making and contractual treaties Jan Klabbers, The Concept of Treaty in International Law (Kluwer Law International 1996) 25.

26 Ekaterina Yahyaoui Krivenko, 'The "Reservations Dialogue" as a Constitution-Making Process' (2014) 16 International Community Law Review 306, 310. 
treaties belong to a normative category which does not generate international mutual relations ${ }^{27}$. Another opinion which reflects the normativity of human rights treaties asserts that beyond representing the consensus between states, human rights treaties show the state admitting the international norms in their relations with the citizens through a unilateral act ${ }^{28}$. According to these views, it is possible to say that human rights treaties do not take up contractual balance and by themselves they abolish the need for party equation. In this case to supervise the compliance of the parties to the human rights treaty needs another sort of mean, a judicial tool or an enforcement authority $^{29}$.

It is accepted both by the doctrine and practice that reciprocity principle has a limited application in international human rights treaty obligations of states ${ }^{30}$. Moreover, the Human Rights Committee in General Comment 24 emphasizes that the principle of reciprocity cannot be applied in human rights treaties ${ }^{31}$. The International Law Commission's Special Rapporteur Pellet, remarks that the human rights rules are not reciprocal by nature, generally ${ }^{32}$. In addition to this, again Pellet in his first report ascertains that the VCLT system based on reciprocity would be incapable in human rights treaties ${ }^{33}$.

The principle of reciprocity has two powers; the first one is the creative force which seeks balance between costs and benefits and the second one is the supervision power, which basically urges states to fulfill their obligations to obtain their rights ${ }^{34}$. The reciprocity principle is also an enforcement tool within a contractual treaty preventing noncompliance tendencies.

As stated above, in human rights treaties, reciprocity does not have this function, they are separated from standard treaties with their content and beneficiaries ${ }^{35}$. The ICJ in its Genocide decision describes the situation and remarks that in human rights treaties rather than the advantages of states the raison d'etre of the treaty, constitutes the high objective of the treaty is intended, also this common interest prevents the perfect contractual balance ${ }^{36}$. An infringer state is not devoid of its rights that are

27 Belinda Clark, 'The Vienna Convention Reservations Regime and the Convention of Discrimination Against Women' (1991) 85 American Journal of International Law 281, 287.

28 Parisi, Ševčenko, (n 22) 37.

29 Liesbeth Lijnzaad, Reservation to UN Human Rights Treaties: Ratify or Ruin? (Martinus Nijhoff Publishers 1995) 68.

30 Marco Milanovic, 'Linos-Alexander Scilianos, Reservations to Treaties: An Introduction', (2013) 24 EJIL 1055, 1057.

31 UNHRC, General Comment adopted by the Human Rights Committee under article 40, paragraph 4, of the International Covenant on Civil and Political Rights (11 November 1994) UN Doc CCPR/C/21/Rev.1/Add.6, para 17.

32 Alain Pellet, State Sovereignty and the Protection of Fundamental Human Rights: an International Law Perspective (Pugwash Occasional Papers 2000) 39.

33 ILC, 'First Report on the Law and Practice relating to Reservations to Treaties, by Mr. Alain Pellet, Special Rapporteur' (30 May 1994) UN Doc A/CN.4/470, para 139

34 Lijnzaad (n 29) 69-70.

35 ibid 110.

36 Reservations to the Convention of Genocide (n 9) 21. 
stemming from the same treaty because the treaty in principle does not regulate the rights of states.

Basically it can be said that a state without gaining any right undertakes the obligations in human rights treaties. This is also stated by the European Commission of Human Rights (EComHR) in the Austria v. Italy decision with the phrase "the objective is not creating mutual and subjective rights for high contracting parties, but to protect from violation of high contracting parties" ${ }^{\prime 37}$. Another judicial organ, the Inter-American Court of Human Rights in its Effects of Reservations decision characterizes the object and purpose of human rights treaties, irrespective of nationality issues, to protect fundamental rights of people from their home state and the other state parties ${ }^{38}$. These regional judicial decisions reflect the international consistency on the same point, the conflict of objectives between the human rights treaties and reciprocity.

It is available for state parties to use reciprocity when declaring, accepting or objecting reservations as a tool for enforcement because of the effects of reservations and the reaction to them. However, the accepting state could not take advantage of the acceptance and have to fulfill its obligations, originating from the treaty, in human rights treaties ${ }^{39}$. This feature of human rights treaties excludes the individual supervision and there have been attempts to cover this lacuna by monitoring bodies established by treaties ${ }^{40}$. The ineffectiveness of the reservation in the bilateral application, prompted other states to tacitly accept the reservation ${ }^{41}$, also this deprives the reservation even of the individual evaluation of state parties.

To conclude, it should be said that reciprocity is not totally nonfunctional in human rights treaties, as an example to this limited impact, the accepting or objecting states cannot be invited by the reserving state to fulfill their obligations originating from the treaty ${ }^{42}$. Beyond that, the reciprocity principle cannot carry out its supervision function in international human rights treaties, because of their abovementioned features which are not built on contractual balance. As a result of reciprocity not working or being a subjective mechanism to supervise the parties and their reservations in human rights treaties, the tendency to establish their monitoring bodies exists. As mentioned above, if the useful tool of reciprocity does not perform, the international system requires other useful tools for judiciary or enforcement means.

37 Austria v Italy App no 788/60 (Commission Decision, 11 January 1961)

38 The Effect of Reservations on the Entry into Force of the American Convention, Advisory Opinion OC-2/82, InterAmerican Court of Human Rights (24 September 1982)

39 ILC, Guide to Practice on Reservations to Treaties Report of the International Law Commission on the work of its 63th session (26 April- 3 June and 4 July- 12 August 2011) Un Doc A/66/10/Add.1, 4.2.5.; Göçer, (n 4) 70.

40 Kasey Lowe McCall-Smith, 'Reservations to Human Rights Treaties' (DPhil thesis, University of Edinburgh, 2012 ) 254.

41 Lijnzaad (n 29) 112.

42 Pellet, Müller (n 11) 535. 


\section{Reservations' Compatibility with the Object and Purpose}

As mentioned above the liberty of formulating reservations in human rights treaties is important to bind maximum number of states possible, however the system based on reciprocity in the VCLT causes some problems on the application in human rights treaties. In this part, the problems in the Vienna System and the proposals from theory and practice -especially the ILC's Guide to Practice- to solve them will be discussed.

According to the principle in article 19, when the treaty does not prohibit declaring reservations or it permits specific kinds of reservations and the reservation is consistent with this rule, a state party can declare a reservation but it has to be compatible with the object and purpose of the treaty. Article 20 regulates the reservations in specific kinds of treaties and the reactions to them from the other parties. The system causes problems mainly in two points. First of all, the relationship between the $19^{\text {th }}$ and $20^{\text {th }}$ articles of the VCLT and secondly what is the object and purpose of a treaty and how the object and purpose of a treaty is going to be determined are ambiguous parts of the law of reservations.

\section{A. Two Different Doctrines in the VCLT: Permissibility and Opposability}

Article 19 of the VCLT regulates the terms for the validity of reservations, and article 20 regulates the acceptance and objection of a reservation by other state parties and the consequences of these reactions. In practice states apply article 20 and accept or object to a reservation, even if the reservation is invalid from the beginning, because the compatibility test included in the article 19 does not prescribe a certain process $^{43}$. There is no expression in the VCLT regarding what happens with the acceptance of an incompatible reservation ${ }^{44}$. The apparent importance of article 20 relies on the absence of exact consequences of incompatibility and the regulation of accepting and objecting invalid reservations.

There is no visible, described connection between these two articles and also no obstacles for a state accepting a reservation which is incompatible with the object and purpose ${ }^{45}$. Even though, accepting a reservation will not make it compatible $a b$ initio $^{46}$, because of the ambiguity, these two articles cannot be implemented together properly. Unlike the objective validity terms in article 19, article 20 does not consider the content of the reservation and leaves its fate to the state party's preference which is free in accepting or objecting $\mathrm{it}^{47}$. As to us, this consequence is coherent because

43 Göçer (n 4) 57. Hence, according to Göçer, in this subjectivist system parties acting according to article 20 are not obliged to consider the terms in article 19 .

44 Coccia (n 14) 23.

45 Françoise Hampson 'Specific Human Rights Issues Reservations to Human Rights Treaties-Final Working Paper Submitted' UN Economic and Social Council Commission on Human Rights E/CN.4/Sub.2/2004/42 (2004) para. 30.

46 Göçer (n 4) 58.

47 Coccia (n 14) 23. 
the permissibility doctrine considers the context of the reservation in the case of the object and purpose test but the opposability doctrine does not consider the reservation itself, it is about the reaction of other state parties to the reservation.

Thus, there exist two possible commentaries about the relevance of these articles, the first one is to understand article 19 as a doctrinal statement which can help states in reacting reservations, while considering that state parties can determine the validity of the reservations. In the Genocide Advisory Opinion, the ICJ accepted the object and purpose test as a limitation for the freedom of state parties and the individual decision of a state on acceptance or objection of a reservation must be made according to the compatibility with the object and purpose ${ }^{48}$. In the same direction with this commentary, Bowett asserts that a reservation, if it is not compatible -independent from the other state party's acceptance- is prohibited, also as a matter of law, the acceptance is unlawful ${ }^{49}$. Clearly, this can be understood as article 20 is only applicable for reservations which are ensuring the terms in article $19^{50}$. According to this view accepting a reservation that does not ensure the terms in article 19, is nonfunctional even illegal. But the Guide to Practice distinguishes the treaty law and law of responsibility and accepts the solution that formulating an impermissible reservation has consequences under the law of treaties and it does not entail the responsibility of the reserving state ${ }^{51}$. As to that, a state can object to a reservation whether it is admissible or not ${ }^{52}$; accepting an impermissible reservation is not ipso facto impermissible ${ }^{53}$.

Pursuant to the opposability view, in the period of objection the permissibility rules in article 19 function $^{54}$, after the end of 12 months without objection or after the explicit acceptance of the reservation there will be no impact of permissibility rules. As a response to this, Simma supports that the opposability rule highlights a system that reservations' only becoming invalid by the objections of the state parties is totally inappropriate for human rights treaties ${ }^{55}$. Attributing the validity of the reservation to the individual conduct of the state parties' against the reservation, contravenes the objective, law-making structure of human rights treaties.

In short, the opposability view represents that if a reservation which is not objected by state parties in 12 months could not become invalid ${ }^{56}$ then, on the other hand,

48 Reservations to the Convention of Genocide (n 9) 24,26.

49 D W Bowett, 'Reservations to Non-Restricted Multilateral Treaties' (1976) 48 British Ybk Intl L 67, 77-83.

50 Coccia (n 14) 24.

51 Guide to Practice (n 39) 3.3.2.

52 ibid 2.6.2.; Hampson (n 45) para 30.

53 Guide to Practice (n 39) 3.4.1.; Hampson (n 45) para 30.

54 Bruno Simma, Gleider I. Hernandez, 'Legal Consequences of an Impermissible Reservation to a Human Rights Treaty: Where Do We Stand?' in Enzo Cannizzaro (ed), The Law of Treaties Beyond the Vienna Convention (OUP 2011) 62.

55 ibid 62.

56 Curtis Bradley, Jack Goldsmith, 'Treaties, Human Rights and Conditional Consent' (2000) 149 University of Pennsylvania Law Review 399, 434-435. 
permissibility supporters assert that the rules of article 20 can only be applied if the reservation provides the conditions stated under article 19. According to the supporters of the permissibility view, a reservation after a long time from its acceptance can be invalidated because of incompatibility ${ }^{57}$. The problem arises from the point that the incompatibility of a reservation can be justified without a time limit which is unfavorable for the stability of the treaty regime, having unstable treaty relations is not a situation desired by state parties.

The ILC also asserts that, the validity of a reservation cannot be determined by a state party's attitude ${ }^{58}$. A reservation must provide the terms in article 19 objectively, and if it is valid for them, it can be accepted or objected by other state parties according to article 20. As to the Guide to Practice, a state party's acceptance does not make a reservation permissible or valid ${ }^{59}$, if a reservation is impermissible according to article 19 after acceptance by the other party it will continue to be impermissible and invalid. Simma justifiably remarks that article 20 is about the legal effects of reservations, not the validity of them, and also, article 20 cannot be applied to an incompatible reservation ${ }^{60}$. But, as asserted above, there is no signal for the priority between the articles 19 and 20, so these contradictory approaches arise from the regulation itself. Pellet points that out this lacuna (or confusion) in the VCLT is left to state practices, monitoring bodies of treaties and tribunals to be filled ${ }^{61}$.

According to the ILC's approach, the permissibility doctrine is theoretically correct. However, state practice, except for human rights treaties, is described through the opposability doctrine ${ }^{62}$. Application of opposability doctrine is not coherent with human rights treaties, as the monitoring of other states is not based upon their rights or obligations owed to them. The opposability doctrine remains elusive because of the political features of reservations in general, that's why the opposability doctrine can correspond to treaties which are strictly contractual and reciprocal in nature ${ }^{63}$.

There are two main problems with this resolution: the authority to decide the compatibility and the legal consequences of the invalid reservation ${ }^{64}$. The legal consequences of an invalid reservation are regarded in three different possibilities: the first one is the surgical doctrine, without the provision its reservation has been declared, the state stays party to the treaty; the second one is the backlash doctrine,

\footnotetext{
57 Roslyn Moloney, 'Incompatible Reservations to Human Rights Treaties: Severability and the Problem of State Consent' (2004) 5 Melbourne Journal of International Law 155, 157.

58 UNGA ‘Report of the International Law Commission' UN GAOR 65th Session Supp No 10 UN Doc A/65/10 (2010) para 68.

59 Guide to Practice (n 39) 3.4.1

60 Simma, Hernandez (n 54) 62.

61 Pellet, Müller (n 11) 545.

62 Kasey L McCall-Smith, 'Severing Reservations' (2014) 63 International Law Quarterly 599, 609.

63 Klabbers (n 18) 181.; Göçer (n 4) 60, 75.; ibid 614.

64 Moloney (n 57) 158
} 
the will of the state to participate in the treaty becomes invalid with the incompatible reservation; the third one is the severability doctrine which cuts the incompatible reservation out of state's will and the state stays party to the treaty ${ }^{65}$.

The severability doctrine has been developed through practice, especially by the praxis of monitoring bodies or decisions of courts in international human rights law ${ }^{66}$. Distinctively discussing the severability doctrine, it seems the midway between the first and second doctrines and adopted by monitoring bodies, however, this doctrine itself has its own problems. In the definition of severability doctrine "the reservation which is not essential to the state's consent to be bound" ${ }^{67}$ statement is used. A state's will to be party of a treaty whether it cannot declare a reservation to it, is an assumption; also the reservation becomes invalid without the will of the state, with the judgment that it is not essential to the consent to be bound. According to the ILC only the state itself can determine the essentiality of its reservation ${ }^{68}$. Objectively, from the ratification document of the state a deduction can be done about essentiality ${ }^{69}$, but according to other doctrinal views, this document cannot guide on this matter ${ }^{70}$.

Specific to the International Covenant on Civil and Political Rights' (ICCPR) monitoring body Human Rights Committee, severability is the general consequence of invalid reservations in human rights treaties ${ }^{71}$, which was applied in USA's reservation to the death penalty and applied by ECHR in several cases like Belilos v. Switzerland and Loizidou v. Turkey ${ }^{72}$.

Even if severability is implemented, there is no way to find out the state's real intention in declaring the reservation. The purpose of this system is to keep the state bound with the treaty. However, the decision about the essentiality of a reservation cannot be taken objectively by any organ because a reservation itself is subjective, for Klabbers it is a political ${ }^{73}$ tool. As a consequence of its political character, states have the liberty to object to a reservation on any basis or no basis at all ${ }^{74}$.

The proposed system of the ILC declared in the Guide to Practice, the reserving state can make a choice between being bound without a reservation or opting out

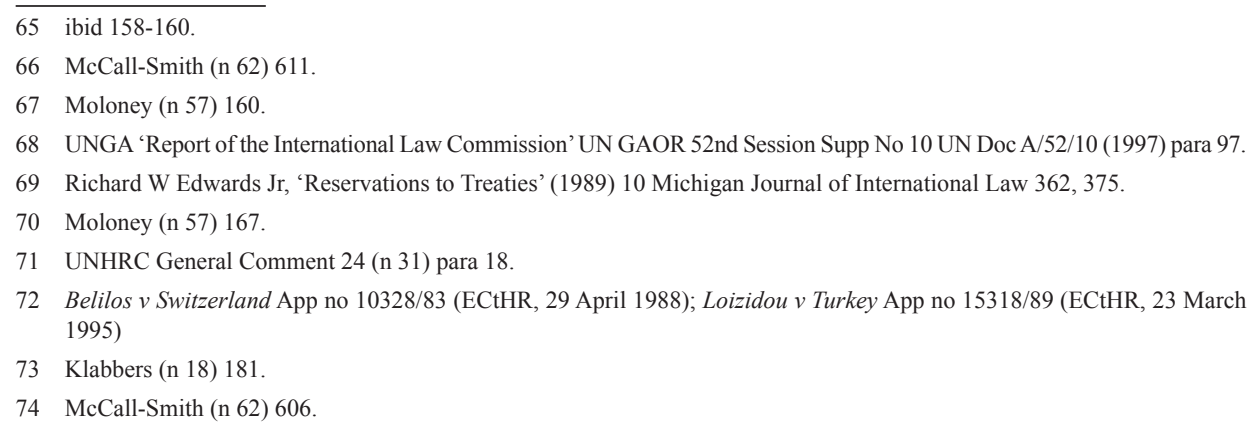


of the treaty ${ }^{75}$. Silence has given meaning, as staying party, the former reserving state can declare its will to opt-out every time, if a monitoring body decides the invalidity, the state has 12 months to declare its intention to opt-out. This solution seems practical and realistic, but in the case of absence of a monitoring body, the status of the reservation becomes ambiguous again.

\section{B. The Evaluation of Compatibility with the Object and Purpose: Monitoring Bodies}

In the Guide to Practice, assessing the permissibility of a reservation is stated as the duty of party states and international organizations, dispute settlement bodies and monitoring bodies according to their respective competences ${ }^{76}$. Permissibility is especially problematic and requires an instrument in case of incompatibility with the object and purpose, however the other conditions of permissibility may be proved objectively. It becomes vivid for a treaty to have a monitoring body to ensure objective supervision, in our case objective mechanism for judicial and enforcement issues needed especially to decide the object and purpose of a treaty and to apply article $19^{77}$. However, a monitoring body expanding its authority due to its uncertain competence makes states doubtful about either becoming a party to a treaty or formulating a reservation to the provision on the authority of the monitoring body. Within this direction, the Guide to Practice does not determine the competence of monitoring bodies and a monitoring body may not have the authority to determine the validity of reservations. Nevertheless, the lack of a judicial organ that can make binding decisions on the interpretation of the treaty, can cause an 'unworkable' object and purpose criteria ${ }^{78}$.

The actual performance of a functioning monitoring body related to the topic of this study is determining the object and purpose of its treaty. Pellet, in the final report on reservations, clarifies how to determine the object and purpose: the content of the treaty, the title and its preamble must be assessed in its own context and with bona fides if needed preparatory work and state practices will be subsidiary ${ }^{79}$. The ILC Guide to Practice on Reservations describes the object and purpose of the treaty as the essential elements composing its raison d'etre ${ }^{80}$, this definition itself needs a definition and it is vital to determine what are the essential elements and raison d'etre of a treaty to adjudicate the validity of reservations. On the other hand, because of the

\footnotetext{
75 Guide to Practice (n 39) 4.5.3.

76 ibid 3.2.

77 Anja Seibert-Fohr, 'The Potentials of the Vienna Convention on the Law of Treaties with Respect to Reservations to Human Rights Treaties' in Ineta Ziemele (ed), Reservations to Human Rights Treaties and the Vienna Convention Regime: Conflict, Harmony or Reconciliation (Martinus Nijhoff Publishers 2004) 204.

78 Isabelle Buffard, Karl Zemanek, 'The "Object and Purpose” of a Treaty: An Enigma?' (1998) 3 Austrian Review of International \& European Law 311, 342.

79 Guide to Practice (n 39) 3.1.5.1.

80 ibid 3.1.5.
} 
controversial nature of defining the object and purpose, the expression in Guide to Practice 3.1.5 may be understood as a methodological tool for helping to find out the object and purpose of the treaty rather than defining $i^{81}$.

In this part, two issues will be clarified, the first is the authority of monitoring bodies, and the second is the determination of raison d'etre of the treaty, to find out the object and purpose.

\section{The Competence of Monitoring Bodies}

Generally, the charge loaded to a treaty monitoring body is to exercise authority within the treaty order in respect of this study to assess the validity of a reservation. A reservation not providing the terms in article 19 is null and void ${ }^{82}$, and should be invalidated proactively by the monitoring body ${ }^{83}$. However, the monitoring body may not have this authority in all cases.

As Pellet stated, the authority of the monitoring body amounts to that assigned with the treaty ${ }^{84}$. In practice various amounts of authorities can be given to monitoring bodies, the basis of this delegation is the will of the state parties. Article 31/3-b of the VCLT states the interpretative function of the monitoring bodies - this function will be effective in determining the object and purpose of a treaty that needs interpretation to determine $i^{85}$.

Not all views accept the determination of the validity of a reservation within the limits of the monitoring bodies' authority. As a practical example, the monitoring body of The International Convention on the Elimination of All Forms of Racial Discrimination rejects the use of this function ${ }^{86}$. But the general tendency is to accept this authority. An example of this view is from the Committee Against Torture, which accepts determining its authority to decide the validity of a reservation within the frame of the $\mathrm{VCLT}^{87}$. To explain the source of the authority of monitoring bodies, some authors use the "competence-competence" principle ${ }^{88}$, which means a mechanism should decide its jurisdiction primarily. Despite this principle, a monitoring body's

81 Zeynep Elibol Brönneke, 'Uluslararası İnsan Hakları Sözleşmelerine Koyulan Çekinceler Çerçevesinde Hedef ve Amaçla Bağdaşmama Ölçütü ve Türkiye Uygulaması' (PhD thesis, Istanbul University, 2017) 105-111, 123.

82 ibid 4.5.1.

83 Christian Walter, 'Section 2: Reservations' in Oliver Dörr, Kirsten Schmalenbach (eds), Vienna Convention on the Law of Treaties: A Commentary (Springer 2012) 277.

84 UN GAOR (n 68) para 82.

85 McCall-Smith (n 40) 232.

86 UNGA 'Committee on the Elimination of Racial Discrimination Report' UN GAOR 33rd Session Supp No 18 UN Doc A/33/18 (1978) para 374.: In the article 20 of the Convention it is stated that "A reservation shall be considered incompatible or inhibitive if at least two thirds of the States Parties to this Convention object to it."

87 ILC, Fifth Report on the Reservations to Treaties by Mr. Alain Pellet, Special Rapporteur (1 May- 9 June and 10 July- 18 August 2000) Un Doc A/CN.4/508, para 13.

88 Manuel Rama-Montaldo, 'Human Rights Conventions and Reservations to Treaties' in Héctor Gros Espiell Amicorum Liber: Human Person and International Law (Bruylant 1997) v2, 1271. 
functioning must not cause ultra vires ${ }^{89}$ on the other hand, the state parties may accept assessing the validity of reservations as broadening the authority and given consent can turn into a loose foundation.

The problems originated from states declaring interpretative declarations in the effect of reservations on the ICCPR, so the Human Rights Committee took action and brought out General Comment 24, aiming to maximize the efficiency of the ICCPR ${ }^{90}$. Unlike the previous comments, General Comment 24 was accepted as a revolutionary attempt because it decided on the authority and functioning of the system ${ }^{91}$. Three main points took place in General Comment 24; the committee has the legal authority to decide which reservations are valid, to decide the reservations permissibility, it must be compatible with the object and purpose, as to the severability in the situation of invalid reservation the state stays party to the treaty without reservation and the monitoring body resolves the consent of the state ${ }^{92}$. In the Loizidou case, the ECHR assesses Turkey's consent and decides the continuation of its member status, and also its own competence as the monitoring body ${ }^{93}$.

The Guide to Practice indicates that the competence of a monitoring body must be formulated including the assessment of the validity of the reservation and for the existing ones, measures could be adopted to the same ends ${ }^{94}$. Related to that, a distinction should be made between regional and global monitoring bodies. Regional treaty systems are based on regional common grounds which are stronger than global agreements, while monitoring bodies of global treaties granted limited power ${ }^{95}$. Surely it will be less troublesome to reach a consensus in regional treaties because states in the same region usually share a common background, but in global treaties the need is to counterbalance the expectancies of states from different backgrounds, also the monitoring bodies of regional treaties tend to use broader authority ${ }^{96}$.

\section{The Object and Purpose of International Human Rights Treaties}

In the Genocide Advisory Opinion, the ICJ states the object and purpose of the convention limits the freedom of making reservations ${ }^{97}$. As a limiting factor of freedom of states, determining the object and purpose of a treaty has a gravity in treaty law but

89 UN GAOR (n 68) para 83.

90 Baylis (n 13) 278.

91 ibid 285.

92 UNHRC General Comment 24 (n 31) para 1-17.

93 W A Schabas, 'Reservations to Human Rights Treaties: Time for Innovation and Reform', Canadian Yearbook of International Law (1995) 32 Canadian Ybk Intl L 39, 74.

94 Guide to Practice (n 39) 3.2.2.

95 Baylis (n 13) 323.

96 Christina M. Cerna, 'Universality of Human Rights and Cultural Diversity: Implementation of Human Rights in Different Socio-Cultural Contexts', (1994) 16 Human Rights Quarterly 740, 749.

97 Reservations to the Convention of Genocide (n 9) 24 
the task is complex. Referring to Pellet's object and purpose determination formula again, from the final report on reservations, would be illustrative: The content of the treaty, the title and its preamble must be assessed in its context and with bona fides, if needed preparation work and state practices will be subsidiary.

For Schabas, this determination is a matter of interpretation; and to determine the object and purpose of a treaty, it had to be interpreted under the light of its object and purpose ${ }^{98}$ according to VCLT article $31 / 1$. This shows how inextricable the issue is. In human rights treaties, the essential instruments of the treaty cannot be identified steadily, however it would be helpful to protect the basis-core of the treaty and let parties formulate reservations to the other parts considering their social, economic and cultural situations ${ }^{99}$. This basis-core formulation also does not directly help to find out the object and purpose but the test proposed by the Inter-American Court of Human Rights is more result-oriented, that reserving the inalienable rights do not cause incompatibility in case of not totally depriving of the enjoyment of a right $^{100}$, the compatibility problem solved in deciding the deprivation proportion from enjoying the right. This assessment has two levels, at first the determination whether it is inalienable or not, secondly the examination of deprivation. When approaching human rights treaties as law-making, order founding instruments, any reservation can be claimed incompatible with the object and purpose because it contravenes the ideal of protection, but this monolithic approach restrains state parties' will and blocks universal participation. Also, this order can be established by meeting on common ground rather than binding parties with exactly the same terms.

The Human Rights Commission in its report asserts that to assess the validity of a reservation, its relation with other rights and indivisibility must be considered ${ }^{101}$. This refers to a cumulative judgment, its place in the treaty and relation with the other rights must be considered ${ }^{102}$ to find out the validity of the reservation.

Lastly, a distinction must be made between the types of human rights treaties, i. e. treaties regulating a specific right and general human rights treaties. To determine the object and purpose of specific human rights treaties requires less effort than general human rights treaties which are multifaceted ${ }^{103}$ and including rights as a catalog-list.

98 Schabas (n 93) 48.; VCLT art 31/1: A treaty shall be interpreted in good faith under the ordinary meaning to be given to the terms of the treaty in their context and the light of its object and purpose.

99 Catherine Redgwell, 'Universality or Integrity? Some Reflections on Reservations to General Multilateral Treaties' (1993) 64 British Ybk Intl L 245, 281.

100 Restrictions to the Death Penalty (Arts. 4(2) and 4(4) American Convention on Human Rights), Advisory Opinion OC3/83, Inter-American Court of Human Rights (8 September 1983) para 66.

101 UNGA 'Report of the International Law Commission 59 $9^{\text {th }}$ Session' UN GAOR 62nd Session Supp No 10 UN Doc A/62/10 (2007) 115.

102 Guide to Practice-Commentary (n 39) 3.1.5.1., paras 3, 4.

103 Beyza Özturanlı, 'Uluslararası Hukuk Komisyonu Çalışmaları Çerçevesinde Uluslararası Andlaşmalara Getirilen Çekincelere İlişkin Hukuki Rejim’ (2012) 22 İstanbul Ticaret Üniversitesi Sosyal Bilimler Dergisi 471, 491. 
The object and purpose of the Convention Against Torture can be determined to prevent torture. But in treaties protecting human rights different in subject - as in a cataloglist - the object and purpose can be decided to guarantee these rights. According to Hampson, the object of a human rights treaty is not to undertake a certain number of obligations, the goal is respecting, protecting and promoting human rights ${ }^{104}$.

In that vein, according to the Guide to Practice, reservations must be admissible if the enjoyment of all the rights which no derogation permitted did not restrained substantially in the catalog sort of human rights treaties ${ }^{105}$. The ILC in its report asserts that the effect of the reservation to the right must be assessed if the enjoyment of the right is prevented substantially, there can be incompatibility with the object and purpose ${ }^{106}$ and by the way, adopts the test proposed by the Inter-American Court of Human Rights stated above. In this case, every right and reservation has to be assessed individually since there is no order of priority between rights, a general assessment among rights would not be possible. Reservation to a right if it is not a jus cogens norm will not be regarded invalid at first sight, the normative characteristics of the right must be evaluated to determine the validity. Also, it can be proper to use the "deprivation proportion" test proposed by the Inter-American Court of Human Rights instead of using the object and purpose test, which also, as to us seems, more appropriate for international human rights treaties.

As mentioned above to determine the object and purpose of human rights treaties and applying the object and purpose test to them may not help to reach the conclusion intended with article 19 of the VCLT. The object and purpose can be determined vast enough to prevent the proper application of the test. On the other hand, assessing a reservations' deprivation proportion firstly enables the individual assessment of rights in an international human rights treaty and secondly in comparison with the object and purpose test it refers to the direct relation between the right and reservation. In the method proposed by the Inter-American Court, not the provision's importance and essentiality in the formulation of the treaty but the right's normative status in international human rights law evaluated to decide the validity of the reservation according to the permissibility doctrine. These differences make the deprivation proportion test more suitable and less equivocal in the implementation of international human rights treaties.

\section{Conclusion}

Problems originated from the different aspects of human rights treaties and caused complexities in the application of the VCLT. The individual supervision effect of the reciprocity rule is of no use in international human rights treaties and also the acceptance

104 Hampson (n 45) para 50.

105 Guide to Practice (n 39) 3.1.5.4.

106 UN GAOR (n 101) 116. 
of reservations does not function as in synallagmatic treaties. However, objections to reservations still maintain their importance unless an ante hoc supervision is provided ${ }^{107}$. Also, the universality of the treaty has a major importance and the parties to the treaties should be more in number to ensure more peoples' rights with international protection; so in reservation regimes, while liberal options pave the way for international inclusion, the essence of the treaty must be protected to constitute a normative system. Reaching the high ideals and standards of the international community cannot be maintained by prohibiting the reservations, therefore in human rights treaties reservations are indispensable. Permitting reservations enables effectuating the rights of more peoples from different regional, cultural, and religious systems. As mentioned above, Klabbers accepted the universality and integrity as twin ideals, the consequences of the liberation reveal the requirement of an institutionalized system in the application of reservations especially in some types of treaties.

The rules of the VCLT regarding the validity of a reservation, articles 19 and 20, conflicts with each other and the application of them cause problems in objectivity. Against the individualist system of opposability in article 20, the permissibility system in article 19 has to be applied priorly, and a reservation ensuring the terms in article 19 must become acceptable or opposable by the states according to article 20. The implementation of these articles requires institutionalization, a monitoring body to determine the validity of a reservation for the sake of objectivity. Despite the views from the doctrine, there are no exact and precise rules about the authority of monitoring bodies and the determination of the object and purpose. Rules in the Guide to Practice are non-binding in composition and intrinsically guiding principles. The Vienna System is said to be suitable for different types of treaties because it establishes a balance between universality and integrity ${ }^{108}$, but the point is more than the universality and integrity tension, the Vienna system also produces other problems. Also, Pellet calls attention to the negotiators of treaties who find the Vienna system satisfactory and suitable ${ }^{109}$. However, because of being vague and open-ended, the VCLT rules remained incapable of solving the problems arising from the practice ${ }^{110}$. The Vienna system is blurry in practice and does not provide certain methods for the application of reservations, and with the Guide to Practice, the ILC and Pellet struggled to solve the problems arising from the application of the VCLT, but there may exist some structural and institutional ones. It is essential in the application of a treaty that the reservation conflicting with the object and purpose of the treaty must not be determined as of compatible or not by an objective mechanism, at least. However as mentioned above, the ILC incisively adopted the view to convert the

107 Elibol Brönneke (n 81) 216-217, 230.

108 Alain Pellet, 'The ILC Guide to Practice on Reservations to Treaties' (2013) 24 EJIL 1061 2013, 1078.

109 ibid 1077.

110 Elif Uzun, 'Uluslararası Hukuk Komisyonu'nun “Andlaşmalara Çekince İleri Sürülmesi için Uygulama Rehberi” Üzerine Betimsel Bir İnceleme’ (2013) 12 TAAD 185, 187-188. 
object and purpose test in VCLT article 19 to the deprivation proportion test with the effect of practice in human rights treaties.

As we tried to mention and illustrate above, even if the Guide to Practice is comprehensive and detailed, the problems remain eloquently in case of human rights treaties or general, which requires more institutions and indirectly more restrictions on the sovereignty of states. In the case of international human rights treaties, other state parties may not have much concern about the reservations which do not affect their benefits thoroughly and intercept their rights. They may even admit or respond impermissible reservations in human rights treaties on subjective grounds for any reason. In treaties that are drafted after a productive negotiation process, parties may tend to formulate reservations less because they can reflect their will in the treaty directly. After the end of the negotiation process, the subjective ground pales and the application of the reservation rules in the VCLT or Guide to Practice requires a more institutional procedure.

Grant Support: The author received no grant support for this work.

\section{Bibliography}

\section{Cases}

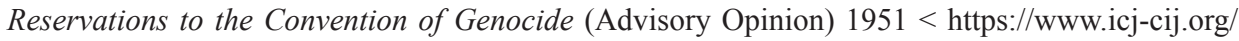
files/case-related/12/012-19510528-ADV-01-00-EN.pdf > accessed 25 September 2019 [21].

Austria v Italy App no 788/60 (EComHR Decision, 11 January 1961)

The Effect of Reservations on the Entry into Force of the American Convention, Advisory Opinion OC-2/82, Inter-American Court of Human Rights (24 September 1982)

Restrictions to the Death Penalty (Arts. 4(2) and 4(4) American Convention on Human Rights), Advisory Opinion OC-3/83, Inter-American Court of Human Rights (8 September 1983)

Belilos v Switzerland App no 10328/83 (ECtHR, 29 April 1988);

Loizidou v Turkey App no 15318/89 (ECtHR, 23 March 1995)

\section{United Nations Documents}

ILC, 'First Report on the Law and Practice relating to Reservations to Treaties, by Mr. Alain Pellet, Special Rapporteur' (30 May 1994) UN Doc A/CN.4/470

ILC, 'Second Report on Reservations to Treaties by Mr. Alain Pellet, Special Rapporteur' (10 May13 June 1996) UN Doc A/CN.4/477\&Corr.1\&2 and Add.1\&Corr.1-4

ILC, Fifth Report on the Reservations to Treaties by Mr. Alain Pellet, Special Rapporteur (1 May- 9 June and 10 July- 18 August 2000) Un Doc A/CN.4/508

ILC, Fourteenth Report on Reservations to Treaties, by Mr. Alain Pellet, Special Rapporteur (2 April, 22 May and 7 August 2009) UN Doc A/CN.4/614

ILC, Guide to Practice on Reservations to Treaties Report of the International Law Commission on the work of its 63th session (26 April- 3 June and 4 July- 12 August 2011) Un Doc A/66/10/Add.1 
UN Economic and Social Council Commission on Human Rights 'Specific Human Rights Issues Reservations to Human Rights Treaties-Final Working Paper Submitted' by Françoise Hampson E/CN.4/Sub.2/2004/42 (2004)

UNGA 'Committee on the Elimination of Racial Discrimination Report' UN GAOR 33rd Session Supp No 18 UN Doc A/33/18 (1978)

UNGA 'Report of the International Law Commission' UN GAOR 52nd Session Supp No 10 UN Doc A/52/10 (1997)

UNGA 'Report of the International Law Commission' UN GAOR 61th Session Supp No 10 UN Doc A/61/10 (2006)

UNGA 'Report of the International Law Commission 59 ${ }^{\text {th }}$ Session' UN GAOR 62nd Session Supp No 10 UN Doc A/62/10 (2007)

UNGA 'Report of the International Law Commission' UN GAOR 65th Session Supp No 10 UN Doc A/65/10 (2010)

UNHRC, General Comment adopted by the Human Rights Committee under article 40, paragraph 4, of the International Covenant on Civil and Political Rights (11 November 1994) UN Doc CCPR/C/21/Rev.1/Add.6

\section{Books and Journals}

Akdoğan E, Belirsizlik Kuramı Yönünden Uluslararası Andlaşmalarda Çekinceler (Yetkin 2018)

Baylis E A, 'General Comment 24: Confronting the Problem of Reservations to Human Rights Treaties' (1999) 17 Berkeley Journal of International Law 277.

Bowett D W, 'Reservations to Non-Restricted Multilateral Treaties' (1976) 48 British Ybk Intl L 67

Bradley C and Goldsmith J, 'Treaties, Human Rights and Conditional Consent' (2000) 149 University of Pennsylvania Law Review 399

Brölmann C, 'Law-Making Treaties: Form and Function in International Law' (2005) 74 Nordic Journal of International Law 383

Buffard I, Zemanek K, 'The "Object and Purpose” of a Treaty: An Enigma?' (1998) 3 Austrian Review of International \& European Law 311

Cerna C M, 'Universality of Human Rights and Cultural Diversity: Implementation of Human Rights in Different Socio-Cultural Contexts', (1994) 16 Human Rights Quarterly 740

Clark B, 'The Vienna Convention Reservations Regime and the Convention of Discrimination Against Women' (1991) 85 American Journal of International Law 281.

Coccia M, 'Reservations to Multilateral Treaties on Human Rights' (1985) 15 California Western International Law Journal 1

Devidal P, 'Reservations, Human Rights Treaties in the 21st Century: from Universality to Integrity' (LLM thesis, Georgia Law, 2003)

Elibol Brönneke Z, 'Uluslararası İnsan Hakları Sözleşmelerine Koyulan Çekinceler Çerçevesinde Hedef ve Amaçla Bağdaşmama Ölçütü ve Türkiye Uygulaması' (PhD thesis, Istanbul University, 2017)

Edwards Jr R W, 'Reservations to Treaties’ (1989) 10 Michigan Journal of International Law 362

Göçer M, Uluslararası Hukuk ve İnsan Haklarının Uluslararası Korunması (Seçkin 2002)

Klabbers J, The Concept of Treaty in International Law (Kluwer Law International 1996) 
Klabbers J, 'On Human Rights Treaties, Contractual Conceptions and Reservations' in Ineta Ziemele (ed), Reservations to Human Rights Treaties and the Vienna Convention Regime: Conflict, Harmony or Reconciliation (Martinus Nijhoff Publishers 2004)

Krivenko E Y, 'The "Reservations Dialogue" as a Constitution-Making Process' (2014) 16 International Community Law Review 306

Lijnzaad L, Reservation to UN Human Rights Treaties: Ratify or Ruin? (Martinus Nijhoff Publishers 1995)

McCall-Smith K L, 'Reservations to Human Rights Treaties' (DPhil thesis, University of Edinburgh, 2012)

McCall-Smith K L, 'Severing Reservations' (2014) 63 International Law Quarterly 599

Milanovic M and Scilianos L A, 'Reservations to Treaties: An Introduction', (2013) 24 EJIL 1055

Moloney R, 'Incompatible Reservations to Human Rights Treaties: Severability and the Problem of State Consent' (2004) 5 Melbourne Journal of International Law 155

Özman A, Milletlerarası Andlaşmalarda Çekinceler (İhtirazi Kayıtlar) (Sevinç 1970)

Özturanlı B, 'Uluslararası Hukuk Komisyonu Çalışmaları Çerçevesinde Uluslararası Andlaşmalara Getirilen Çekincelere İlişkin Hukuki Rejim' (2012) 22 İstanbul Ticaret Üniversitesi Sosyal Bilimler Dergisi 471

Parisi F and Ševčenko C, 'Treaty Reservations and The Economics of Article 21(1) of the Vienna Convention' (2003) 21 Berkeley Journal of International Law 1

Pellet A, State Sovereignty and the Protection of Fundamental Human Rights: an International Law Perspective (Pugwash Occasional Papers 2000)

Pellet A and Müller D, 'Reservations to Human Rights Treaties: Not An Absolute Evil...' in Ulrich Fastenrath and others (eds), From Bilateralism to Community Interest (OUP 2011)

Pellet A, 'The ILC Guide to Practice on Reservations to Treaties' (2013) 24 EJIL 1061

Piper C L, 'Reservations to Multilateral Treaties, The Goal of Universality' (1985) 71 Iowa Law Review 295

Rama-Montaldo M, 'Human Rights Conventions and Reservations to Treaties' in Héctor Gros Espiell Amicorum Liber: Human Person and International Law (Bruylant 1997) v2

Redgwell C, 'Universality or Integrity? Some Reflections on Reservations to General Multilateral Treaties' (1993) 64 British Ybk Intl L 245

Schabas W A, 'Reservations to Human Rights Treaties: Time for Innovation and Reform', Canadian Yearbook of International Law (1995) 32 Canadian Ybk Intl L 39

Seibert-Fohr A, 'The Potentials of the Vienna Convention on the Law of Treaties with Respect to Reservations to Human Rights Treaties' in Ineta Ziemele (ed), Reservations to Human Rights Treaties and the Vienna Convention Regime: Conflict, Harmony or Reconciliation (Martinus Nijhoff Publishers 2004)

Simma B and Hernandez G I, 'Legal Consequences of an Impermissible Reservation to a Human Rights Treaty: Where Do We Stand?' in Enzo Cannizzaro (ed), The Law of Treaties Beyond the Vienna Convention (OUP 2011)

Uzun E, 'Uluslararası Hukuk Komisyonu'nun “Andlaşmalara Çekince İleri Sürülmesi için Uygulama Rehberi” Üzerine Betimsel Bir İnceleme’ (2013) 12 TAAD 185

Walter C, 'Section 2: Reservations' in Oliver Dörr, Kirsten Schmalenbach (eds), Vienna Convention on the Law of Treaties: A Commentary (Springer 2012) 